\title{
METHOD OF BIOCHEMICAL CHANGE CORRECTIONS IN THE BOAR ORGANISMS WITH TOXICANT-INDUCED REPRODUCTIVE DYSFUNCTIONS
}

\author{
Naumenko S. V., Koshevoi V. I., Siehodin O. B. \\ Kharkiv State Zooveterinary Academy, Kharkiv, Ukraine, e-mail: frolka001@gmail.com
}

\begin{abstract}
Summary. The pathogenetic mechanism of reproductive diseases is oxidative stress, which is manifested by an increase in lipid peroxidation and a decrease in antioxidant potential. The aim of the study was to develop a method for the correction of biochemical changes in the body of boars with toxicant-induced reproductive dysfunctions using drugs based on nanobiomaterials, based on reducing lipoperoxidation, neutralization of toxic substances by antioxidant protection increasing of animals and endocrine activity stimulating of their gonads. The article presents the results of research on the effectiveness of the complex drug 'Karafand+OV,Zn', which contains carotenoids, phytoandrogens and nanomaterials - nanoparticles of gadolinium orthovanadate, activated by europium, and zinc carbonate. Experimental toxicant-induced reproductive dysfunctions were caused by feeding sodium nitrate at a dose of $0.3 \mathrm{~g} \mathrm{NO}_{3}^{-} / \mathrm{kg} \mathrm{body}^{-}$ weight. The drug was administered in a dose of $15 \mathrm{ml}$ per male, orally, once a day for 14 days. Blood samples for test were taken before and on the $20^{\text {th }}$ day after drug administration. Conventional biochemical methods were used, as well as chemiluminometry and enzyme-linked immunosorbent assay. There was a positive effect of the developed drug on the hormonal state (testosterone concentration increased by $91.8 \%(20.6 \pm 0.32 \mathrm{nmol} / \mathrm{l}, \mathrm{p}<0.001)$, the content of vitamin $\mathrm{A}$ increased 1.3 times $(0.65 \pm 0.02 \mu \mathrm{mol} / \mathrm{l}, \mathrm{p}<0.001)$ and zinc by $47.6 \%(24.8 \pm 0.86 \mu \mathrm{mol} / \mathrm{l}, \mathrm{p}<0.001)$, the dynamics of lipoperoxidation processes (the concentration of malonic dialdehyde in the serum was reduced by $53.2 \%$ $(0.394 \pm 0.01 \mu \mathrm{mol} / \mathrm{l}, \mathrm{p}<0.001)$ ) and the system of antioxidant protection of boars (increased activity of catalase and superoxide dismutase in serum by $71.5 \%\left(41.4 \pm 1.03 \mu \mathrm{mol} / \mathrm{H}_{2} \mathrm{O}_{2} / \mathrm{l}-\mathrm{min}, \mathrm{p}<0.001\right)$ and $54.8 \%$ ( $8.98 \pm 0.09$ st. un./mgHb, $\mathrm{p}<0.001)$, respectively), increased the content of reduced glutathione by $23.2 \%$, indicators of the oxygen metabolism system (concentration 2,3-diphosphoglycerate increased 1.3 times $(1.4 \pm 0.03 \mathrm{mmol} / \mathrm{l}$, $\mathrm{p}<0.001$ ), the activation of which reduces the hypoxic state. The total antioxidant activity of boars increased, as evidenced by a decrease in the light sum of chemiluminescence of serum by $47.6 \%(4.4 \pm 0.15 \mathrm{un}$., $\mathrm{p}<0.001)$. The results of research convincingly testify to the high efficiency of the use of the complex drug 'Karafand+OV,Zn' as a means of correction of toxicant-induced reproductive dysfunctions in boars and proves the possibility of its use in practical veterinary andrology
\end{abstract}

Keywords: complex drug, Karafand+OV,Zn, nanobiomaterials, lipoperoxidation, antioxidant protection, oxygen metabolism

Introduction. The negative impact of environmental factors on the body of males causes the development of a complex of pathological processes - reproductive diseases, characterized by biochemical, hormonal and structural changes and lead to dysfunction of the testes, in particular hypofertility (Koshevoi et al., 2015).

The pathogenetic mechanism of reproductive disorders is oxidative stress (Agarwal et al., 2014). Oxidative stress is manifested by an increase in lipid peroxidation and a decrease in antioxidant potential (Danchuk, Karpovskyi and Danchuk, 2016; Khariv et al., 2016). It is known that the high content of thiobarbituric acid reactants leads to a deterioration in the quality of sperm and its fertilizing ability (Chornozub, 2013).

One of the leading causes of such conditions is the action of toxic factors on the body of animals through food, for example, the receipt of toxic doses of nitrates from water and feed (De Celis, Pedrón-Nuevo and FeriaVelasco, 1996; Hunchak et al., 2010). In an experimental model of chronic nitrate-nitrite toxicosis, we showed its effect on the dynamics of the prooxidant-antioxidant system, oxygen metabolism and sperm quality (Koshevoi et al., 2016; Naumenko, 2020).
The development of modern means of reproductive disorder corrections is based on the interdependent action on the processes of lipoperoxidation, neutralization of toxic substances by increasing the antioxidant protection of animals and stimulating the endocrine activity of their gonads (Koshevoi et al., 2015, 2016).

The aim of the study was to develop a method for the correction of biochemical changes in the body of boars with toxicant-induced reproductive dysfunctions using drugs based on nanobiomaterials.

Materials and methods. The research was conducted on boars belonging to the FP 'Vlada' (Yurivka, Pavlohrad District, Dnipropetrovsk Region). The method of correction of toxicant-induced reproductive dysfunctions includes the use of a complex drug 'Karafand+OV,Zn', synthesized in the laboratories of the Department of Veterinary Reproductology of the Kharkiv State Zooveterinary Academy and the Nanostructured Materials Department of Institute for Scintillation Materials of the National Academy of Sciences of Ukraine under the agreement on scientific and practical cooperation. The developed preparation in $1.0 \mathrm{~cm}^{3}$ contains carotenoids $(10.0 \pm 0.75 \mathrm{mg})$, biologically active 
substances from the rhizome of marsh calamus $(1.0 \pm 0.05 \mathrm{mg})$ and nanomaterials - nanoparticles of gadolinium orthovanadate activated by europium $(0.00015 \pm 0.00001 \mathrm{mg})$ and zinc carbonate $(2.0 \pm 0.1 \mathrm{mg})$, the basis of the pharmaceutical composition was refined oil.

The group of animals for production testing consisted of clinically healthy males $(n=5)$, live weight $291.0 \pm 5.3 \mathrm{~kg}$ aged $4-6$ years, kept on a standard diet and had free access to water. Experimental toxicant-induced reproductive dysfunctions were induced by feeding sodium nitrate at a dose of $0.3 \mathrm{~g} \mathrm{NO}_{3}^{-} / \mathrm{kg}$ body weight of the male. The drug was administered in a dose of $15 \mathrm{ml}$ per male, orally, once a day for 14 days. Blood samples for test were taken before and on the $20^{\text {th }}$ day after drug administration.

The effectiveness of the developed drug was determined by changes in the content of vitamin A, zinc, the dynamics of the prooxidant-antioxidant system, oxygen metabolism and hormonal state. In the laboratory of the Department of Veterinary Reproductology, the content of vitamin A was determined by the Bessey method in the modification by Levchenko et al. (Vlizlo, 2012). Indexes of oxygen metabolism were determined: the number of erythrocytes by photocolorimetric registration of the studied samples optical density on KFK-3 at a wavelength of $670 \mathrm{~nm}$, the hemoglobin concentration was investigated by hemoglobin cyanide method followed by photocolorimetry at an optical path of $540 \mathrm{~nm}$, the content of 2,3-diphosphoglycerate in the erythrocyte suspension was determined spectrophotometrically (Dyce method modified by Apukhovska). The content of zinc in the serum was determined by atomic adsorption spectrophotometry at the Department of Animal Internal Medicine of the Kharkiv State Zooveterinary Academy.

In boars the following parameters were spectrophotometrically determined: the dynamics of the prooxidant-antioxidant system was determined by the content of the final product of lipoperoxidation malonic dialdehyde by reaction with thiobarbituric acid (Fedorova, Korshunova and Larsky, 1983), and the activity of superoxide dismutase by the degree of inhibition of the reaction by the enzyme to reduce nitroblue tetrazolium in the presence of $\mathrm{NADH}$ and phenazine methosulfate (Dubinina et al., 1990), catalase activity on the ability of hydrogen peroxide to form a stable complex with ammonium molybdate, the color intensity of which was measured at $\lambda=410 \mathrm{~nm}$ (Korolyuk et al., 1988), the amount of reduced glutathione was determined by the Butler method using Ellman's reagent (Vlizlo, 2012) at the Central Research Laboratory of the National University of Pharmacy.

The general antioxidant activity of boars was studied by chemiluminescent analysis in the laboratory of Institute for Scintillation Materials of the National Academy of Sciences of Ukraine.
The concentration of testosterone in the serum was determined in the State Institution 'V. Danilevsky Institute for Endocrine Pathology Problems of the National Academy of Medical Sciences of Ukraine' using the method of enzyme-linked immunosorbent assay. Statistical processing of the results was conducted by Student's $t$-test (Rebrova, 2002).

Results. In the correction of toxicant-induced reproductive dysfunctions in boars, we found high efficiency of the developed drug. In particular, there was a positive effect on the hormonal state, the content of vitamin A and zinc (Table 1).

Table 1- The effect of the complex drug 'Karafand+OV,Zn' on the content of vitamin A, zinc and testosterone concentration in boars $(\mathrm{M} \pm \mathrm{m})$

\begin{tabular}{|l|c|c|}
\hline \multicolumn{1}{|c|}{ Indexes } & $\begin{array}{c}\text { Before ad- } \\
\text { ministration }\end{array}$ & $\begin{array}{c}\text { After ad- } \\
\text { ministration }\end{array}$ \\
\hline Vitamin $\mathrm{A}, \mu \mathrm{mol} / \mathrm{l}$ & $0.28 \pm 0.012$ & $0.65 \pm 0.02^{*}$ \\
\hline Zinc, $\mu \mathrm{mol} / \mathrm{l}$ & $16.8 \pm 0.374$ & $24.8 \pm 0.86^{*}$ \\
\hline $\begin{array}{l}\text { Testosterone concentration, } \\
\text { nmol/l }\end{array}$ & $10.74 \pm 0.214$ & $20.6 \pm 0.32^{\star}$ \\
\hline
\end{tabular}

Note. ${ }^{*}-\mathrm{p}<0.001$ compared to pre-introduction.

The content of vitamin A in boars increased almost 1.3 times $(0.65 \pm 0.02 \mu \mathrm{mol} / \mathrm{l}, \quad \mathrm{p}<0.001)$, while the amount of zinc in the serum increased by $47.6 \%(24.8 \pm 0$, $86 \mu \mathrm{mol} / \mathrm{l}, \mathrm{p}<0.001)$. Normalization of the hormonal state was noted - the concentration of testosterone was higher by $91.8 \%(20.6 \pm 0.32 \mathrm{nmol} / \mathrm{l}, \mathrm{p}<0.001)$ compared to the indicators before administration.

The effect of the drug on the dynamics of lipoperoxidation processes and the system of antioxidant protection of boars was effective (Table 2).

Table 2- Dynamics of the prooxidant-antioxidant system of boars under the action of a complex drug 'Karafand $+\mathrm{OV}, \mathrm{Zn}$ ' $(\mathrm{M} \pm \mathrm{m})$

\begin{tabular}{|l|c|c|}
\hline \multicolumn{1}{|c|}{ Indexes } & $\begin{array}{c}\text { Before ad- } \\
\text { ministration }\end{array}$ & $\begin{array}{c}\text { After ad- } \\
\text { ministration }\end{array}$ \\
\hline \multicolumn{3}{|c|}{ Erythrocyte content: } \\
\hline Malon dialdehyde, $\mu \mathrm{mol} / \mathrm{l}$ & $46.4 \pm 1.21$ & $37.6 \pm 0.81^{\star *}$ \\
\hline Catalase, $\mu \mathrm{mol} / \mathrm{H}_{2} \mathrm{O}_{2} / \mathrm{l}-\mathrm{min}$ & $14.6 \pm 0.68$ & $26.5 \pm 0.52^{\star *}$ \\
\hline $\begin{array}{l}\text { Reduced glutathione, } \\
\mu \mathrm{mol} / \mathrm{l}\end{array}$ & $3.02 \pm 0.16$ & $3.72 \pm 0.15^{\star}$ \\
\hline \multicolumn{3}{|c|}{ Serum content: } \\
\hline Malon dialdehyde, $\mu \mathrm{mol} / \mathrm{l}$ & $0.842 \pm 0.02$ & $0.394 \pm 0.01^{\star *}$ \\
\hline $\begin{array}{l}\text { Catalase, } \mu \mathrm{mol} / \mathrm{H}_{2} \mathrm{O}_{2} / \mathrm{l}-\mathrm{min} \\
\text { Superoxide dismutase, } \\
\text { st. un./mgHb }\end{array}$ & $24.14 \pm 1.02$ & $41.4 \pm 1.03^{\star *}$ \\
\hline $\begin{array}{l}\text { Light-sum of } \\
\text { chemiluminescence, un. }\end{array}$ & $5.8 \pm 0.14$ & $8.98 \pm 0.09^{* *}$ \\
\hline
\end{tabular}

Notes: ${ }^{\star}-\mathrm{p}<0.05,{ }^{*}-\mathrm{p}<0.001$ compared to preintroduction. 
It was noted that the significant effect of the drug 'Karafand+OV,Zn' - was effectively reduced the amount of malonic dialdehyde in serum by $53.2 \%$ $(0.394 \pm 0.01 \mu \mathrm{mol} / \mathrm{l}, \mathrm{p}<0.001)$ and erythrocytes by $19 \%$ $(37.6 \pm 0.81 \mu \mathrm{mol} / \mathrm{l}, \mathrm{p}<0.001)$. Under the action of the drug revealed a significant increase in catalase activity in serum by $71.5 \%\left(41.4 \pm 1.03 \mu \mathrm{mol} / \mathrm{H}_{2} \mathrm{O}_{2} / \mathrm{l}-\mathrm{min}, \mathrm{p}<0.001\right)$ and in erythrocytes by $81.9 \%\left(26.5 \pm 0.52 \mu \mathrm{mol} / \mathrm{H}_{2} \mathrm{O}_{2} / \mathrm{l}-\right.$ $\min , \mathrm{p}<0.001)$. There was an increase in superoxide dismutase activity by $54.8 \%(8.98 \pm 0.09$ st. un./mgHb, $\mathrm{p}<0.001$ ) compared with pre-administration. This is marked in the body of boars by a decrease in the activity of catalase and superoxide dismutase activity (Shostya et al., 2020). The content of reduced glutathione in erythrocytes was probably higher by $23.2 \%$ $(3.72 \pm 0.15 \mu \mathrm{mol} / \mathrm{l}, \mathrm{p}<0.05)$ of the group of animals before drug administration. Similar results of the research of a decrease in the activity of antioxidant enzymes in boars in the testes and epididymis and increasing their values after correction (Tang et al., 2019). The total antioxidant activity of boars increased, as evidenced by a decrease in the light sum of chemiluminescence of serum by $47.6 \%(4.4 \pm 0.15$ un., $\mathrm{p}<0.001)$.

There was also a positive effect of this drug on the indicators of the oxygen metabolism system, the activation of which reduces the hypoxic state observed in the development of toxicosis (Table 3).

An increase in the number of erythrocytes by $44.9 \%$ $\left(7.42 \pm 0.14 \times 10^{12} / \mathrm{l}, \mathrm{p}<0.001\right)$, hemoglobin content by $25.65 \%(106.8 \pm 1.93 \mathrm{~g} / \mathrm{l}, \mathrm{p}<0.001)$ and probable increase in the concentration of 2,3-diphosphoglycerate in erythrocytes by 1.3 times $(1.4 \pm 0.03 \mathrm{mmol} / \mathrm{l}, \mathrm{p}<0.001)$.
Table 3- The state of the system of oxygen metabolism of boars under the action of the complex drug 'Karafand+OV,Zn' $(\mathrm{M} \pm \mathrm{m})$

\begin{tabular}{|l|c|c|}
\hline \multicolumn{1}{|c|}{ Indexes } & $\begin{array}{c}\text { Before ad- } \\
\text { ministration }\end{array}$ & $\begin{array}{c}\text { After ad- } \\
\text { ministration }\end{array}$ \\
\hline Erythrocytes, $\times 10^{12} / 1$ & $5.12 \pm 0.09^{*}$ & $7.42 \pm 0.14^{*}$ \\
\hline $\begin{array}{l}\text { Hemoglobin concentration, } \\
\text { g/l }\end{array}$ & $85 \pm 1.84$ & $106.8 \pm 1.93^{*}$ \\
\hline $\begin{array}{l}\text { 2,3-diphosphoglycerate } \\
\text { concentration, mmol/l }\end{array}$ & $0.6 \pm 0.04$ & $1.4 \pm 0.03^{\star}$ \\
\hline
\end{tabular}

Note. ${ }^{\star}-\mathrm{p}<0.001$ compared to pre-introduction.

Our results coincide with the use of antioxidant enzymes in the liver of wild boars against the background of selenium deficiency occurred during the winter (Jankowiak et al., 2015).

Conclusions. The results of research convincingly show the high efficiency of the complex drug 'Karafand+OV,Zn' as a means of correction of toxicantinduced reproductive dysfunctions in boars, in particular, its positive effect on the prooxidant-antioxidant system (reduction of malonic dialdehyde by 53.2\% $(\mathrm{p}<0.001)$ and increase in the activity of catalase by $81.9 \%(\mathrm{p}<0.001)$ and superoxide dismutase by $54.8 \%(\mathrm{p}<0.001)$, increase in the content of reduced glutathione by $23.2 \%(\mathrm{p}<0.05)$, oxygen metabolism (increase in concentration of 2,3diphosphoglycerate by 1.3 times $(\mathrm{p}<0.001)$ ), homeostasis (increase in vitamin A and zinc by 1.3 times and $47.6 \%$, respectively) and hormonal state (increase in testosterone concentration by $91.8 \%(\mathrm{p}<0.001))$.

\section{References}

Agarwal, A., Mulgund, A., Sharma, R. and Sabanegh, E. (2014) 'Mechanisms of oligozoospermia: an oxidative stress perspective', Systems Biology in Reproductive Medicine, 60(4), pp. 206-216. doi: 10.3109/19396368.2014.918675.

Chornozub, T. V. (2013) Influence of Antioxidant System Condition on Sperm Quality of Breeding Boars and Its Correction [Vplyv stanu antyoksydantnoi systemy na yakist spermy knurivplidnykiv ta yoho korektsiia]. The dissertation thesis for the scientific degree of the candidate of veterinary sciences. Sumy: Sumy National Agrarian University. [in Ukrainian].

Danchuk, O. V., Karpovskyi, V. I. and Danchuk, V. V. (2016) 'Indices of lipid peroxidation intensity in pigs under the influence of stress factors' [Indeksy intensyvnosti peroksydnoho okysnennia lipidiv u svynei za dii stresovoho faktora], Scientific Messenger of Lviv National University of Veterinary Medicine and Biotechnologies named after S. Z. Gzhytskyj. Series: Veterinary Sciences [Naukovyi visnyk Lvivskoho natsionalnoho universytetu veterynarnoi medytsyny ta biotekhnolohii imeni S. Z. Gzhytskoho. Seriia: Veterynarni nauky], 18(1.2), pp.47-50. Available at: http://nbuv.gov.ua/UJRN/nvlnu_2016_18_1(2)_10. [in Ukrainian].

De Celis, R., Pedrón-Nuevo, N. and Feria-Velasco, A. (1996) 'Toxicology of male reproduction in animals and humans',
Archives of Andrology, 37(3), pp.201-218. doi: 10.3109/ 01485019608988523.

Dubinina, E. E., Babenko, G. A., Shcherbak, I. G. and Turkin, V. B. (1990) 'Characteristics of superoxide dismutase of human blood plasma', Free Radical Biology and Medicine, 9(Suppl), p. 130. doi: 10.1016/0891-5849(90)90637-X.

Fedorova, T. N., Korshunova, T. S. and Larsky, E. G. (1983) 'Reactions with thiobarbituric acid for fluorometric determination of the blood malonic dialdehyde' [Reaktsii s tiobarbiturovoy kislotoy dlya opredeleniya malonovogo dial'degida krovi metodom flyuorimetrii], Laboratory Science [Laboratornoe delo], 3, pp. 25-27. [in Russian].

Hunchak, V. M., Hufriy, D. F., Hutyy, B. V., Vasiv, R. O., Khariv, I. I., Khomik, R. I., Murska, S. D. and Guberuk, V. A. (2010) 'Influence of sodium nitrate in toxic doses on system of antioxidant defense and lipid peroxidation in blood of bullcalves' [Vplyv nitratu natriiu u toksychnykh dozakh na systemu antyoksydantnoho zakhystu ta perekysne okysnennia lipidiv u krovi buhaitsiv], The Animal Biology [Biolohiia tvaryn], 12(1), pp. 151-158. Available at: http://nbuv.gov.ua/UJRN/bitv_2010_ 12_1_25. [in Ukrainian].

Jankowiak, D., Pilarczyk, R., $\quad$ Drozd, R., $\quad$ Pilarczyk, B., Tomza-Marciniak, A., Wysocka, G., Rząd, I., Drozd, A. and 
Kuba, J. (2015) 'Activity of antioxidant enzymes in the liver of wild boars (Sus scrofa) from aselenium-deficient area depending on sex, age, and season of the year', Turkish Journal of Biology, 39(1), pp. 129-138. doi: 10.3906/biy-1405-52.

Khariv, M. I., Gutyj, B. V., Butsyak, V. I. and Khariv, I. I. (2016) 'Hematological indices of rat organisms under conditions of oxidative stress and liposomal preparation action' [Hematolohichni pokaznyky orhanizmu shchuriv za umov oksydatsiinoho stresu ta za dii liposomalnoho preparatu], Biological Bulletin of Bogdan Chmelnitskiy Melitopol State Pedagogical University [Biolohichnyi visnyk Melitopolskoho derzhavnoho pedahohichnoho universytetu imeni Bohdana Khmelnytskoho], 6(1), pp. 276-289. doi: 10.15421/201615. [in Ukrainian].

Korolyuk, M. A., Ivanova, L. I., Mayorova, I. G. and Tokarev, V. E. (1988) 'Determination of catalase activity' [Opredelenie aktivnosti katalaz], Laboratory Science [Laboratornoe delo], 1, pp. 16-18. PMID: 2451064. [in Russian].

Koshevoi, V. P., Naumenko, S. V., Koshevoi, V. I., Maliukin, Yu. V., Klochkov, V. K. and Kavok, N. S. (2015) 'Computer monitoring of the indicators of structural and functional conditions of the reproductive system organs in males at deficiency of carotene (vitamin A) and zinc' [Kompiuternyi monitorynh pokaznykiv strukturno-funktsionalnoho stanu orhaniv reproduktyvnoi systemy u samtsiv pry defitsyti karotynu (vitaminu A) ta Tsynku], Problems of Zooengineering and Veterinary Medicine [Problemy zooinzhenerii ta veterynarnoi medytsyny], 31(2), pp. 62-70. Available at: http://nbuv.gov.ua/UJRN/pzvm_2015_ 31(2)_16. [in Ukrainian].

Koshevoi, V. P., $\quad$ Fedorenko, S. Ya., Naumenko, S. V., Ivanchenko, M. M., $\quad$ Onyshchenko, O. V., $\quad$ Besedovska, K. S., Pasternak, A. M., $\quad$ Hladtsinova, I. O. Koshevoi, V. I., Skliarov, P. M., Maliukin, Yu. V., $\quad$ Yefimova, S. L. and Klochkov, V. K. (2016) Complex Preparations Based on NanoBiomaterials and Their Use in Veterinary Reproductology: Methodological Recommendations [Kompleksni preparaty, stvoreni na osnovi nano-biomaterialiv, ta yikh vykorystannia $u$ veterynarnii reproduktolohii: metodychni rekomendatsii]. Dnipropetrovsk: Porohy. [in Ukrainian].

Naumenko, S. V. (2020) 'The state of oxygen metabolism system in males with gonadaldystrophy of the toxic type', Actual Problems of Veterinary Biotechnology and Infectious Pathology of Animals: materials of the annual scientific and practic conference of young scientists, Kyiv, 9 July 2020 [Aktualni problemy veterynarnoi biotekhnolohii ta infektsiinoi patolohii tvaryn: materialy shchorichnoi naukovo-praktychnoi konferentsii molodykh vchenykh, Kyiv, 9 lypnia 2020 r.]. Kyiv: Komprynt, p. 24. Available at: http://ivm.kiev.ua/wp-content/uploads/3бірк а-тез-конференції-2020.pdf.

Rebrova, O. Yu. (2006) Statistical Analysis of Medical Data: Using of STATISTICA Applied Package [Statisticheskiy analiz meditsinskikh dannykh: primenenie paketa prikladnykh programm STATISTICA]. $3^{\text {rd }}$ ed. Moscow: MediaSfera. ISBN 5890840134. [in Russian].

Shostya, M. A., Pavlova, I. V., Chukhlib, Y. V., Kuzmenko, L. M., Kodak, T. S., Bereznytskyi, V. I. and Shaferivskyi, B. S. (2020) 'The influence of humates on pro-oxidant-antioxidant homeostasis in breeding boars during heat stress' [Vplyv humativ na prooksydantno-antyoksydantnyi homeostaz u knuriv-plidnykiv pid chas teplovoho stresu], Bulletin of Poltava State Agrarian Academy [Visnyk Poltavskoi derzhavnoi ahrarnoi akademii], 1, pp. 114-120. doi: 10.31210/visnyk2020.01.13. [in Ukrainian].

Tang, W., Wu, J., Jin, S., He, L., Lin, Q., Luo, F., He, X., Feng, Y., He, B., Bing, P., Li, T. and Yin, Y. (2020) ‘Glutamate and aspartate alleviate testicular/epididymal oxidative stress by supporting antioxidant enzymes and immune defense systems in boars', Science China Life Sciences, 63(1), pp. 116-124. doi: 10.1007/s11427-018-9492-8.

Vlizlo, V. V. (ed.) (2012) Laboratory Methods of Research in Biology, Animal Husbandry and Veterinary Medicine [Laboratorni metody doslidzhen $u$ biolohii, tvarynnytstvi ta veterynarnii medytsyni]. Lviv: Spolom. ISBN 9769666656776. [in Ukrainian]. 